\title{
PENAPISAN ISOLAT RIZOBAKTERI DARI PERAKARAN TANAMAN KEDELAI YANG SEHAT UNTUK PENGENDALIAN PENYAKIT PUSTUL BAKTERI (XANTHOMONAS AXONOPODIS PV. GLYCINES)
}

\author{
Yulmira Yanti ${ }^{1}$, Trimurti Habazar ${ }^{1}$, Zurai Resti ${ }^{1}, \&$ Dewi Suhalita ${ }^{2}$ \\ ${ }^{1}$ Fakultas Pertanian Universitas Andalas, Padang, Sumatera Barat \\ ${ }^{2}$ Mahasiswa Fakultas Pertanian Universitas Andalas, Padang, Sumatera Barat \\ E-mail:yy_anthie@yahoo.com
}

\begin{abstract}
Screening of indigenous rhizobacteria from healthy soybean root to control bacterial pustule (Xanthomonas axonopodis pv. glycines) using in planta technique. Plant growth promoting rhizobacteria are a group of bacteria that actively colonize plant roots, increase plant growth and control plant pathogens. The aim of this study was to obtain rhizobacteri isolates which have the ability to control bacterial pustule and increase growth and yield of soybean. This method based on in planta selection of enhanced competitive soil root-colonizing bacteria from soil samples of healthy soybean root at endemic area of bacterial pustule in Darmasraya District and Sijunjung District, West Sumatera. We characterized only the best rhizobacteri isolates which have ability to control bacterial pustule and to increase growth and yield of soybean. This type of characterization has possibility to find new, easy and cheap biocontrol organisms. Ten Rhizobacteri isolates were introduced via seed treatment $\left(10^{8} \mathrm{cfu} / \mathrm{ml}\right)$ and soil drench to 3 week old soybean seedling. Xanthomonas axonopodis pv. glycines were inoculated to one month old of soybean seedling. The effect of rhizobacteria on disease incidence, disease severity, plant growth and yield of soybean were evaluated. We have found that two selected rhizobacteri isolates from soybean (P12Rz2.1 and P14Rz1.1) were the best isolates in promoting growth and the of the soybean plants with the effectiveness $20.62 \%$ and 20.47 $\%$.
\end{abstract}

Key words: bacterial pustule,Rhizobacteria, soybean, in planta technique

\begin{abstract}
ABSTRAK
Penapisan isolat rizobakteri dari perakaran tanaman kedelai yang sehat untuk pengendalian penyakit pustul bakteri (Xanthomonas axonopodis pv. Glycines). Rizobakteri pemacu pertumbuhan tanaman merupakan kelompok bakteri yang aktif mengkolonisasi akar tanaman, meningkatkan pertumbuhan tanaman dan mengendalikan patogen tanaman. Penelitian ini bertujuan untuk memperoleh isolat rizobakteri yang mampu mengendalikan penyakit pustul bakteri dan meningkatkan pertumbuhan dan hasil kedelai. Metode penelitian berdasarkan pada penapisan secara in planta rizobakteria dari tanah perakaran tanaman kedelai yang sehat dari daerah endemik penyakit pustul bakteri di Kabupaten Darmasraya dan Kabupaten Sijunjung, Sumatera Barat. Selanjutnya isolat bakteri rizobakteria yang dikarakterisasi hanya yang mampu mengendalikan penyakit pustul bakteri dan meningkatkan pertumbuhan serta hasil kedelai Penggunaan teknik ini memungkinkan untuk menemukan agens hayati yang baru, lebih mudah dan murah. sepuluh isolat bakteri rizobakteri diintroduksi pada benih kedelai $\left(10^{8} \mathrm{cfu} / \mathrm{ml}\right)$ dan pada tanah sekeliling tanaman kedelai umur 3 minggu. Tanaman kedelai umur 1 bulan diinokulasi dengan Xanthomonas axonopodis pv. glycines secara pelukaan. Peubah yang diamati adalah insidensi dan severitas penyakit pustul bakteri, pertumbuhan dan hasil kedelai. Hasil penelitian menunjukkan bahwa 2 isolat bakteri rizobakteri dari perakaran kedelai (P12Rz2.1 dan P14Rz1.1) merupakan isolat terbaik dalam meningkatkan pertumbuhan dan hasil kedelai dengan efektivitas $20,62 \%$ dan $20,47 \%$.
\end{abstract}

Kata kunci: kedelai ,rizobakteria indigenus, penyakit pustul bakteri, teknik in planta

\section{PENDAHULUAN}

Kedelai (Glycine $\max$ L.) termasuk salah satu komoditas utama kacang-kacangan yang menjadi andalan nasional karena merupakan sumber protein nabati dan rendah kolesterol (Hasanuddin et al., 2005).
Produktivitas kedelai di Sumatera Barat berfluktuasi, pada tahun 2005 mencapai 1,32 ton/ha, tahun 2006 menurun 1,22 ton/ha, kemudian tahun 2007-2009 terjadi peningkatan dari 1,28 ton/ha menjadi 1,68 ton/ha (Badan Pusat Statistik, 2009). Produktivitas kedelai optimal dapat mencapai 2,00-3,50 ton/ha (Adisarwanto, 2009). 
Salah satu faktor yang dapat mempengaruhi produktivitas tanaman kedelai adalah patogen penyebab penyakit diantaranya penyakit pustul bakteri yang disebabkan oleh Xanthomonas axonopodis pv. glycines (Xag) (Khaeruni, et al., 2007). Penyakit pustul bakteri telah tersebar di Indonesia, seperti di Jawa Barat, Jawa Tengah, Daerah Istimewa Yogyakarta, Lampung, dan Sulawesi Selatan (Machmud, 1987 dalam Dirmawati, 2005) dan Sumatera Barat (Habazar, 1989). Xag dapat menurunkan hasil tanaman kedelai, pada tingkat serangan parah dan kondisi lingkungan mendukung berkisar antara 21-40 \% (Rahayu, 2007). Penyebaran patogen ini sebagian besar melalui benih tanaman yang terinfeksi (seedborne pathogen) (Khaeruni et al., 2007), air dan angin (Goradia et al., 2004.). Selain menyerang kedelai, beberapa galur Xag juga dapat menyerang buncis, kacang panjang, Dolichos uniflorus, Glycine spp., Phaseolus lunatus, P. vulgaris (famili Leguminosae) (Garrity, 2005).

Usaha pengendalian penyakit pustul bakteri yang telah dianjurkan antara lain penggunaan varietas tahan (Semangun, 1990), bakterisida (Sinclair \& Backman, 1989 dalam Dirmawati, 2009), pergiliran tanaman dengan tanaman yang bukan inangnya tidak menanam saat musim hujan (Sweets, 2010), dan memusnahkan sisa tanaman sakit (Mueller, 2010). Penggunaan varietas tahan tidak efektif karena $\mathrm{Xag}$ mempunyai banyak strain dengan fenotipe dan genotipe yang berbeda-beda (Rukayadi et al.,1999). Penggunaan bakterisida berdampak negatif terhadap lingkungan karena residu yang ditinggalkannya bersifat racun serta terjadinya resistensi bakteri terhadap bakterisida tersebut (Habazar et al., 2010).

Alternatif pengendalian yang lebih aman adalah dengan memanfaatkan mikroorganisme sebagai agen biokontrol (Manuellla, et al., 1997). Mikroorganisme yang sudah banyak dilaporkan mampu sebagai agen biokontrol adalah kelompok plant growth promoting rizobakteria (rhizobakteria pemacu pertumbuhan tanaman) dan dikenal sebagai PGPR. PGPR merupakan kelompok bakteri yang heterogen yang ditemukan dalam kompleks rhizosfer, pada permukaan akar dan berasosiasi dalam akar, yang dapat meningkatkan kualitas pertumbuhan tanaman secara langsung ataupun tidak langsung (Joseph et al., 2007).

Kemampuan rizobakteria dalam menginduksi ketahanan tanaman bervariasi dan terlihat kecendrungan isolat yang efektif mengendalikan panyakit tanaman adalah yang berasal dari rizoplan tanaman yang bersangkutan (indigenus). Pengendalian penyakit tanaman dengan mengunakan rizobakteria merupakan salah satu alternatif pengendalian yang ramah lingkungan, berkesinambungan dan dapat diintegrasikan dalam program pengendalian hama terpadu.

Peningkatan ketahanan tanaman terhadap patogen menggunakan rizobakteria dapat merupakan suatu alternatif dalam pengendalian patogen. Beberapa hasil penelitian menunjukkan bahwa penggunaan Pseudomonad fluorescens yang berasal dari bakteri rizobakteria dapat mengendalikan penyakit darah pada pisang yang disebabkan oleh Ralstonia solanecearum (Advinda, 2009), penyakit karat pada daun kopi yang disebabkan oleh Hemileia vastatrix (Shiomi, et al., 2006), dan penyakit hawar bakteri pada kapas yang disebabkan oleh bakteri Xanthomonas axonopodis pv. malvacearum (Rajendran, et al., 2006). Menekan serangan dan perkembangbiakan nematoda bengkak akar (Meloidogyne spp) pada tanaman tomat (Khamariah, 2010).

Rizobakteria dari beberapa genus seperti Pseudomonas, Bacillus dan Azospirillum, dilaporkan mampu meningkatkan pertumbuhan tanaman, menguraikan dinding sel patogen, dan menghambat pertumbuhan patogen dengan menghasilkan senyawa antimikroba seperti siderofor (Chandrashekhara, 2007). Bakteri yang mendukung pertumbuhan tanaman secara tidak langsung memproduksi senyawa antagonis berupa siderofor atau menginduksi sistem pertahanan tanaman terhadap patogen (Diniyah, 2010). Rizobakteria juga dapat berperan sebagai PGPR dengan menyediakan nutrisi tertentu bagi tanaman (Supramana, et al., 2007).

Penelitian ini bertujuan untuk mendapatkan isolat rizobakteri indigenus yang mampu mengendalikan penyakit pustul bakteri dan meningkatkan pertumbuhan dan hasil tanaman kedelai.

\section{METODE PENELITIAN}

Tempat dan Waktu. Penelitian ini dilaksanakan di Laboratorium Mikrobiologi Jurusan Hama dan Penyakit Tumbuhan dan di rumah kawat Fakultas Pertanian Universitas Andalas Limau Manis Padang dari bulan Februari sampai Mei 2011.

Metode. Penelitian dirancang secara Acak Lengkap dengan 12 perlakuan dan 5 ulangan, perlakuannya adalah 10 isolat rizobakteri indigenus yang diintroduksi pada tanaman kedelai St2Rz2.1,St3Rz3.1, St4Rz1.1, St4Rz5.1, Pl1Rz1.1, P12Rz1.1, Pl2Rz2.1, P13Rz2.1, Pl4Rz1.1, P14Rz2.1, Kontrol positif (tanpa Xag dan bakteri rizobakteria) dan Kontrol negatif (inokulasi dengan Xag). Data dianalisis secara sidik ragam, jika berbeda nyata 
dilanjutkan dengan Duncan's New Multiple Range Test (DNMRT) pada taraf 5\%.

Isolasi Rizobakteri. Sampel tanah diambil dari akar kedelai yang berumur 2-3 bulan, telah berbuah, sehat dan pertumbuhannya baik di daerah endemik penyakit pustul bakteri. Sampel tanah diambil 200 g pada kedalaman $20 \mathrm{~cm}$ dan dimasukkan dalam kantong plastik dan disimpan di ruangan $\mathrm{AC}$ pada suhu $25^{\circ} \mathrm{C}$. Isolasi rizobakteri indigenus menggunakan teknik pengenceran seri, sebanyak $1 \mathrm{~g}$ sampel tanah dimasukkan ke dalam tabung reaksi yang telah berisi akuades $10 \mathrm{ml}$ dihomogenkan dengan vortex, diencerkan sampai $10^{-6}$. Suspensi dari masing-masing pengenceran $10^{-5}$ dan $10^{-6}$ diambil $0,1 \mathrm{ml}$, dan dimasukkan ke dalam tabung reaksi yang berisi media NA cair dan dihomogenkan dengan vortex. Suspensi tersebut dimasukkan ke dalam cawan petri dan diinkubasi pada suhu kamar selama $2 \mathrm{x}$ 24 jam. Isolat rizobakteria indigenus yang dipilih dengan ciri, koloni yang dominan tumbuh, bentuk dan sifat koloni yang berbeda dari pengenceran seri (Gambar 1a). Koloni bakteri yang terpilih dimurnikan pada media yang sama dengan metode gores dan diinkubasi selama 48 jam (Gambar 1b). Koloni tunggal bakteri dipindahkan secara aseptik ke dalam microtube yang telah berisi 1 $\mathrm{ml}$ akuades steril dan disimpan dalam refrigerator (Gambar 1c). Isolat bakteri rizobakteria indigenus diamati sifat morfologi (bentuk, warna, ukuran, elevasi) dan fisiologinya (reaksi Gram, reaksi hipersensitif,)

\section{Perbanyakan Isolat Rizobakteri Indigenus.} Peremajaan isolat rizobakteri menggunakan metode gores pada cawan petri berisi medium NA dan diinkubasi selama $2 \times 24$ jam. Perbanyakan rizobakteri untuk diintroduksi pada benih adalah sebagai berikut: koloni tunggal dipindahkan dengan metode gores pada media NA dan diinkubasi selama $2 \times 24$ jam (Gambar 1b),
Selanjutnya disuspensikan dengan akuades steril dan dihomogenkan dengan vortex. Kepadatan populasi ditentukan dengan membandingkan kekeruhan suspensi bakteri dengan larutan McFarland skala 8 (kepadatan populasi bakteri diperkirakan $10^{8} \mathrm{sel} / \mathrm{ml}$ ) (Habazar et al., 2007). Untuk introduksi II, rizobakteria indigenus diperbanyak melalui kultur cair, isolat rizobakteri indigenus diremajakan dengan cara yang sama dengan introduksi I. Tahapan pelaksanan dilakukan sebagai berikut: untuk preculture, 1 koloni rizobakteri dimasukkan ke dalam $25 \mathrm{ml}$ medium NB dalam botol kultur (vol. $50 \mathrm{ml}$ ) dan diinkubasi pada rotary shaker horisontal selama 24 jam. Selanjutnya $1 \mathrm{ml}$ hasil preculture dipindahkan ke dalam $150 \mathrm{ml} \mathrm{NB}$ dalam labu erlenmeyer (vol. $250 \mathrm{ml}$ ) untuk mainculture dan diinkubasi dengan cara yang sama selama $2 \times 24$ jam dengan kecepatan $150 \mathrm{rpm}$ (Yanti dan Resti, 2010) (Gambar 1d). Suspensi rizobakteria dari mainculture diencerkan dan ditentukan kerapatan populasinya dengan mengatur kekeruhannya sama dengan larutan McFarland skala 8 (kepadatan populasi bakteri diperkirakan $10^{8} \mathrm{sel} / \mathrm{ml}$ ) (Habazar et al., 2007) (Gambar 1d).

\section{Introduksi Rizobakteri Indigenus dan Penanaman}

Kedelai. Tanah yang digunakan adalah campuran tanah dan pupuk kandang steril (2:1 v/v). Campuran tanah dan pupuk kandang sebanyak $5 \mathrm{~kg}$ dimasukkan ke dalam polybag. Benih kedelai yang digunakan adalah varietas Anjasmoro yang diperoleh dari daerah sentra produksi tanaman kedelai Kabupaten Dharmasraya dan Kabupaten Sijunjung, Propinsi Sumatera Barat. Benih diuji daya kecambahnya dengan metode Standard Germination Test. Hasil uji daya kecambah benih kedelai varietas ini yaitu 92,67\%. Rizobakteri indigenus diintroduksi pada tanaman kedelai 2 kali, yaitu: (1). Introduksi pada benih. Permukaan benih disterilkan
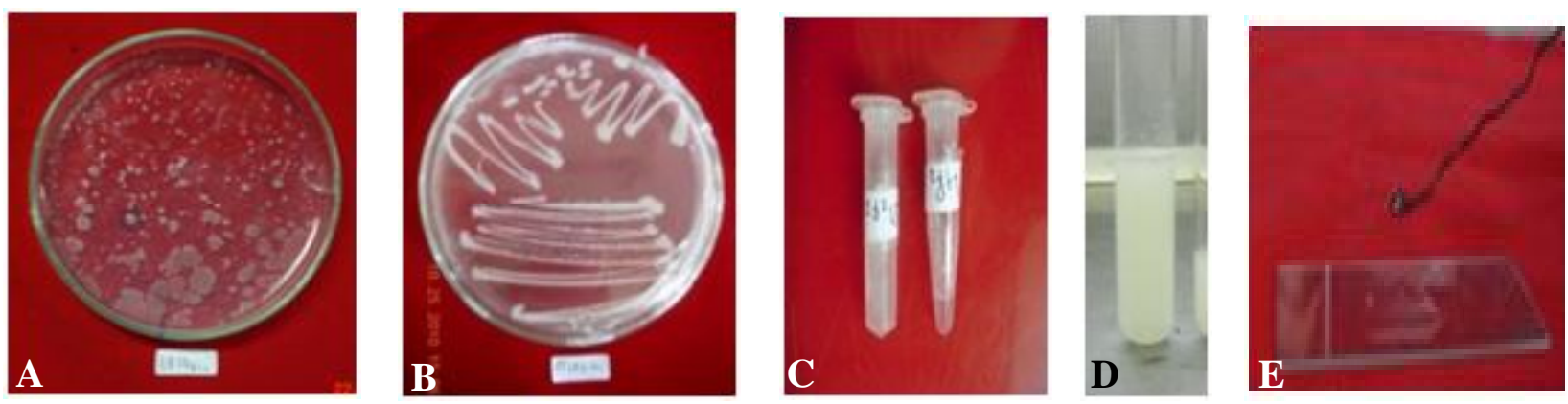

Gambar 1. Isolasi dan perbanyakan rizobakteria. (A) Koloni rizobakteri dari pengenceran seri $10^{-6}$, (B) koloni rizobakteri, (C) penyimpanan rizobakteria dalam tabung ependrof, (D) suspensi isolat rizobakteria indigenus (30hsi), dan (E) rizobakteria reaksi Gram positif. 
dalam larutan $\mathrm{NaOCl} 1 \%$ selama 5 menit, kemudian dicuci dengan akuades dan dibiarkan sampai kering (30 menit). Benih tersebut kemudian direndam dalam suspensi isolat rizobakteri indigenus selama 10 menit (Gambar 2a) dan ditanam dalam polybag; (2) Rizobakteri indigenus diintroduksi setelah tanaman kedelai berumur 3 minggu setelah tanam (mst). Suspensi isolat rizobakteria indigenus sebanyak $10 \mathrm{ml}$ dengan kerapatan $10^{8} \mathrm{sel} / \mathrm{ml}$ diintroduksi melalui penyiraman pada tanah dengan jarak $2 \mathrm{~cm}$ dari pangkal batang (Gambar $2 b$ ).

Perbanyakan dan Inokulasi $X$. a. pv. glycines. Xag diisolasi dari daun kedelai yang memperlihatkan gejala penyakit pustul bakteri dari daerah endemik di Kabupaten Dharmasraya dengan pengenceran seri dan dimurnikan dengan metoda gores. Isolat Xag diuji sifat morfologi, fisiologi, reaksi hipersensitif dan patogenisitasnya (Gambar 3).

Biakan murni Xag dalam cawan Petri ditambah dengan $9 \mathrm{ml}$ aquadest dan dikikis dengan jarum ose. Suspensi Xag dipindahkan ke dalam tabung reaksi menggunakan pipet tetes, dihomogenkan dengan vortex, dan dibandingkan kekeruhannya dengan larutan McFarland skala 6, jika kekeruhannya sama maka kepadatan populasi Xag tersebut diperkirakan $10^{6} \mathrm{sel} /$ ml (Habazar et al., 2007). Inokulasi dilakukan pada tanaman kedelai umur 50 hst pada daun muda sebanyak 3 daun dengan cara daun ditusuk dengan jarum pentul sebanyak 10 tusukan, diolesi dengan suspensi Xag menggunakan kapas pada bagian bawah permukaan daun setelah itu diselubungi dengan plastik bening, dan diinkubasi 5×24 jam (Klement et al., 1990).
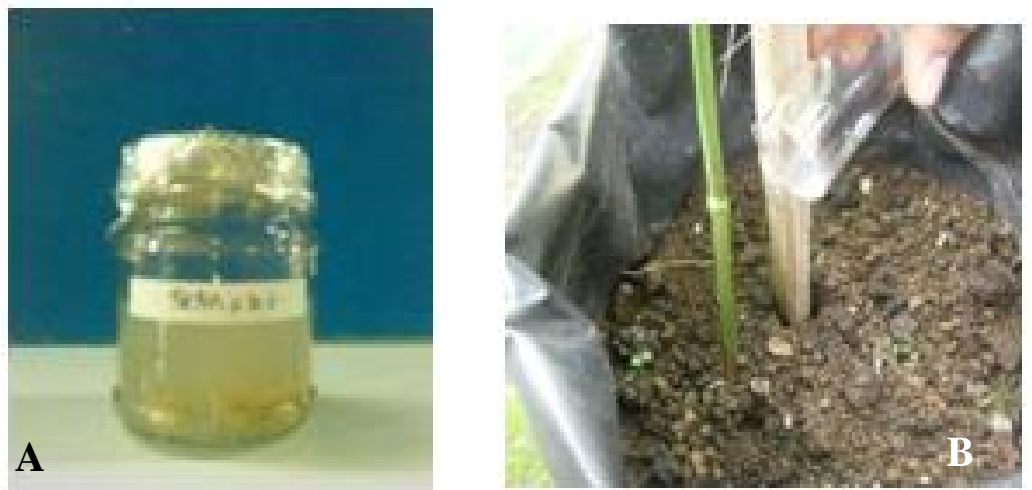

Gambar 2. Introduksi isolat rizobakteria indigenus. (A) Dengan perendaman benih dalam suspensi rizobakteri dan (B) penyiraman bibit tanaman kedelai (21 hst).
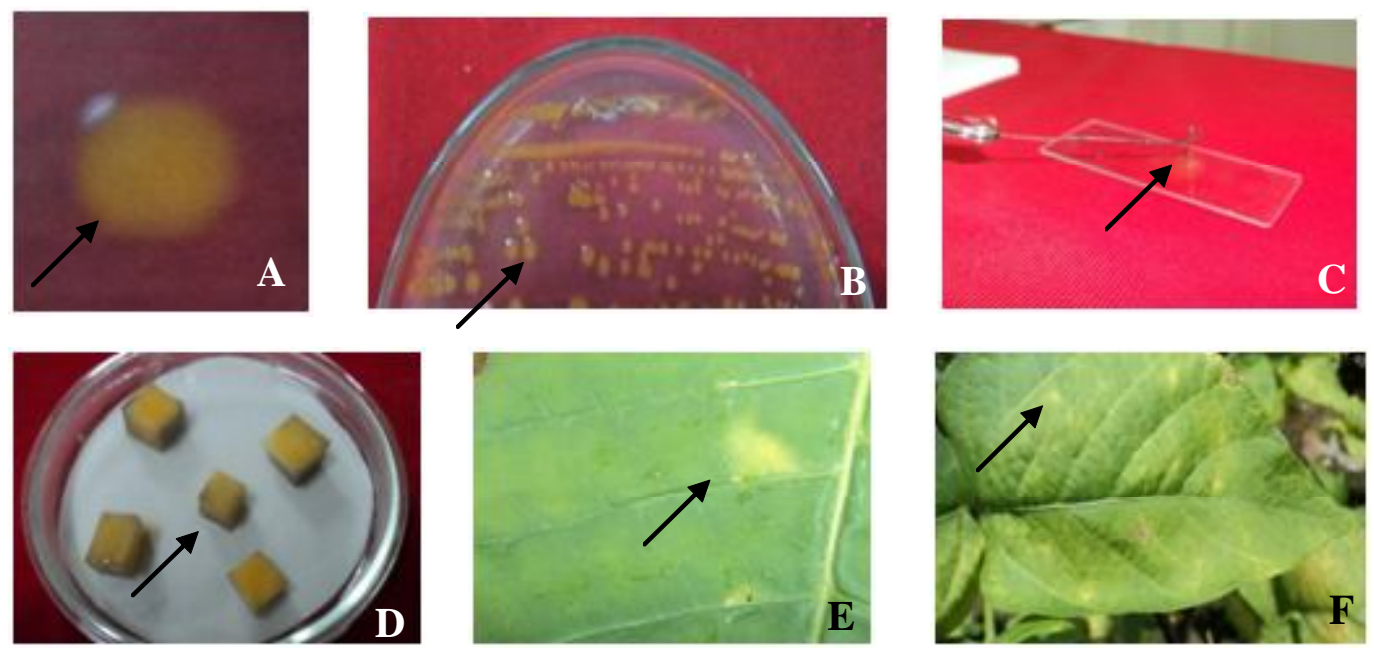

Gambar 3. Morfologi koloni Xag dan fisiologi serta patogenisitas Xag. (A) Morfologi koloni Xag umur 5 hari pada medium NGA, (B) produksi pigmen Xanthomonadin, (C) reaksi Gram negatif, (D) produksi enzim pektinase, $(\mathrm{E})$ reaksi hipersensitif pada daun tembakau + , dan $(\mathrm{F})$ patogenisitas pada daun kedelai+ 
Pemeliharaan Tanaman. Pemeliharaan tanaman kedelai meliputi penyiraman, pemupukan, penyiangan gulma dan pengendalian hama secara mekanis. Pupuk buatan diberikan pada tanaman berumur 14 hst yaitu pupuk N 0,23 gr/polibag (setara dengan $50-75 \mathrm{~kg} / \mathrm{ha}$ ), pupuk SP36 0,3 gr/polybag (setara dengan 50-100 kg/ ha), dan pupuk $\mathrm{KCl} 0,45 \mathrm{gr} /$ polybag (setara dengan 100$150 \mathrm{~kg} / \mathrm{ha}$ ) (Adisarwanto, 2009).

Panen. Polong kedelai dipanen pada umur 88 hari setelah $95 \%$ polong kedelai berwarna cokelat kekuningan dan jumlah daun tersisa pada tanaman hanya sekitar 5-10\% (Adisarwanto, 2009).

Peubah yang Diamati. Karakterisasi rizobakteri yang diamati adalah: morfologi koloni (bentuk, ukuran, warna, elevasi), dan fisiologi (reaksi Gram, produksi pigmen fluoresen, reaksi hipersensitif,). Pengamatann juga dilakukan terhadap persentase kecambah benih kedelai, persentase muncul lapang, perkembangan penyakit pustul bakteri (masa inkubasi, insidensi, severitas, persentase polong terserang, intensitas polong terserang), dan pertumbuhan tanaman (tinggi tanaman, jumlah daun, jumlah cabang, saat muncul bunga pertama, saat muncul polong pertama, berat polong dan berat biji).

\section{HASIL DAN PEMBAHASAN}

Karakter Rizobakteri. Sifat morfologi koloni rizobakteria dari perakaran tanaman kedelai dengan bentuk, ukuran dan warna yang beragam (Gambar 1). Karakter fisiologis rizobakteri menunjukkan bersifat Gram positif (6 isolat), sedangkan Gram nevatif (4 isolat) dan produksi pigmen fluorescens semua isolat negatif . Hasil uji patogenesitasnya pada tanaman tembakau (reaksi hipersensitif), 10 isolat menunjukkan reaksi negatif, yang berarti bukan patogen pada tanaman (Tabel $1)$.

Perkembangan Penyakit Pustul Bakteri. Hampir semua isolat rizobakteri indigenus yang diintroduksi pada tanaman kedelai mampu memperlambat masa inkubasi $X$. a. pv. glycines (Tabel 2). Isolat Pl4Rz1.1 dan St2Rz2.1 lebih lambat masa inkubasinya ( $9,33 \mathrm{hsi})$ dan efektivitas $27,28 \%$ lebih tinggi jika dibandingkan kontrol (7,33 hsi). Insidensi penyakit pustul bakteri lebih rendah pada tanaman kedelai yang diintroduksi dengan isolat rizobakteri indigenus dibanding kontrol, dua isolat terbaik yaitu Pl2Rz2.1 (insidensi 19,33\% dan efektivitas 65,68 $\%$ ) dan P14Rz1.1 (insidensi 21,67\% dan efektivitas 61,53 $\%)$. Hampir semua isolat rizobakteria indigenus yang diintroduksi pada tanaman kedelai mampu menurunkan severitas Xag dibanding kontrol dan meningkatkan ketahanan tanaman dari agak rentan menjadi agak tahan (3 isolat) sampai tahan (6 isolat: Pl2Rz1.1, Pl4Rz1.1, Pl2Rz2.1, Pl1Rz1.1, St4Rz5.1 dan P14Rz2.1).

Hampir semua isolat rizobakteri yang diintroduksi pada tanaman kedelai mampu meningkatkan ketahanan tanaman terhadap penyakit pustul bakteri dari kategori agak rentan (kontrol) menjadi agak tahan ( 2 isolat) dan tahan (6 isolat: Pl2Rz2.1; P14Rz1.1; Pl2Rz1.1; Pl1Rz1.1; P14Rz2.1 dan St4Rz5.1). Tanaman kedelai yang diintroduksi dengan isolat P12Rz2.1 menunjukkan severitas yang paling rendah $(5,33 \%)$ dengan efektivitas $77,48 \%$. Hasil penelitian ini menunjukkan bahwa isolat $\mathrm{RB}$ indigenus mampu menghambat perkembangan $\mathrm{Xag}$

Tabel 1. Karakterisasi bentuk morfologi dan fisiologi isolat rizobakteria dari perakaran tanaman kedelai

\begin{tabular}{|c|c|c|c|c|c|c|c|}
\hline \multirow{2}{*}{$\begin{array}{l}\text { Nama } \\
\text { isolat }\end{array}$} & \multicolumn{4}{|c|}{ Ciri koloni } & \multirow{2}{*}{$\begin{array}{c}\text { Reaksi } \\
\text { Gram }\end{array}$} & \multirow{2}{*}{$\begin{array}{c}\text { Reaksi } \\
\text { hipersensitif }\end{array}$} & \multirow{2}{*}{$\begin{array}{l}\text { Produks } \\
\text { pigmen } \\
\text { fluoreser }\end{array}$} \\
\hline & Bentuk & Warna & $\begin{array}{c}\text { Ukuran } \\
\text { (mm) }\end{array}$ & Elevasi & & & \\
\hline P14Rz1.1 & Iregular & Putih mengkilat & 2,00 & Cembung & + & - & - \\
\hline St2Rz2.1 & Bulat & Putih susu & 1,50 & Cembung & + & - & - \\
\hline P12Rz1.1 & Bulat & putih keruh & 4,50 & Datar & + & - & - \\
\hline Pl1Rz1.1 & Ireguler & Putih keruh & 2,00 & Datar & + & - & - \\
\hline Pl2Rz2.1 & Bulat & Putih keruh & 3,00 & Cembung & - & - & - \\
\hline P14Rz2.1 & Bulat & Putih keruh & 3,50 & Datar & - & - & - \\
\hline St3RZ3.1 & Ireguler & Putih mengkilat & 4,00 & Cembung & + & - & - \\
\hline St4Rz1.1 & Ireguler & Putih susu & 3,00 & Cembung & + & - & - \\
\hline St4Rz5.1 & Bulat & Putih susu & 2,50 & Datar & - & - & - \\
\hline P13Rz2.1 & Rhizoid & Putih susu & 4,00 & Datar & - & - & - \\
\hline
\end{tabular}


Tabel 2. Perkembangan penyakit pustul bakteri pada tanaman kedelai setelah diintroduksi dengan isolat rizobakteri indigenus

\begin{tabular}{|c|c|c|c|c|c|c|c|}
\hline \multirow{2}{*}{$\begin{array}{l}\text { Nama } \\
\text { isolat }\end{array}$} & \multicolumn{2}{|c|}{ Masa inkubasi } & \multicolumn{2}{|c|}{ Insidensi (26 hsi) } & \multicolumn{2}{|c|}{ Severitas (26 hsi) } & \multirow{2}{*}{$\begin{array}{c}\text { Reaksi } \\
\text { ketahanan }^{\text {c }}\end{array}$} \\
\hline & Hsi & $\begin{array}{c}\text { Efektivitas } \\
(\%)^{\mathrm{a})}\end{array}$ & $\%$ & $\begin{array}{c}\text { Efektivitas } \\
(\%)^{\text {b })}\end{array}$ & $\%$ & $\begin{array}{c}\text { Efektivitas } \\
(\%)^{\mathrm{b}}\end{array}$ & \\
\hline P14Rz1.1 & $9,33 \mathrm{a}$ & 27,28 & $22,65 \mathrm{c}$ & 61,27 & $7,87 \mathrm{e}$ & 67,36 & Tahan \\
\hline St2Rz2.1 & $9,33 \mathrm{a}$ & 27,28 & $23,65 \mathrm{bc}$ & 58,46 & 10,33 bcde & 57,15 & Agak tahan \\
\hline P12Rz1.1 & $8,33 \mathrm{~b}$ & 13,64 & $29,03 \mathrm{bc}$ & 49,01 & $5,57 \mathrm{e}$ & 76,89 & Tahan \\
\hline P11Rz1.1 & $8,00 \mathrm{bc}$ & 9,14 & $27,08 \mathrm{bc}$ & 52,43 & 9,05 cde & 62,21 & Tahan \\
\hline P12Rz2.1 & $8,00 \mathrm{bc}$ & 9,14 & $19,79 \mathrm{c}$ & 65,24 & $8,59 \mathrm{de}$ & 64,33 & Tahan \\
\hline P14Rz2.1 & $8,00 \mathrm{bc}$ & 9,14 & $25,33 \mathrm{bc}$ & 55,52 & 9,14 cde & 62,46 & Tahan \\
\hline St3RZ3.1 & $8,00 \mathrm{bc}$ & 9,14 & $39,02 \mathrm{~b}$ & 31,46 & $14,70 \mathrm{bc}$ & 39,03 & Agak tahan \\
\hline St4Rz1.1 & $8,00 \mathrm{bc}$ & 9,14 & $30,78 \mathrm{bc}$ & 45,93 & $15,41 \mathrm{~b}$ & 36,08 & Agak rentan \\
\hline St4Rz5.1 & $8,00 \mathrm{bc}$ & 9,14 & $26,72 \mathrm{bc}$ & 53,05 & 9,10 cde & 62,05 & Tahan \\
\hline P13Rz2.1 & $7,66 \mathrm{bc}$ & 3,68 & $33,64 \mathrm{bc}$ & 40,91 & $13,95 \mathrm{bcd}$ & 42,14 & Agak tahan \\
\hline \multirow[t]{2}{*}{ Kontrol } & $7,33 \mathrm{c}$ & 0,00 & $56,94 \mathrm{a}$ & 0,00 & $24,11 \mathrm{a}$ & 0,00 & Agak rentan \\
\hline & \multicolumn{2}{|c|}{$\mathrm{KK}=7,06 \%$} & \multicolumn{2}{|c|}{$\mathrm{KK}=33,09 \%$} & \multicolumn{2}{|c|}{$\mathrm{KK}=30,43 \%$} & \\
\hline
\end{tabular}

${ }^{a}$ Efektivitas $=(\mathrm{K}-\mathrm{P} / \mathrm{K}) \times 100 \%, \mathrm{~K}=$ Kontrol dan $\mathrm{P}=$ Perlakuan. ${ }^{\mathrm{b}}$ Efektivitas= $(\mathrm{P}-\mathrm{K} / \mathrm{K}) \times 100 \%$. ${ }^{\mathrm{c}}$ Sivan \& Chet (1986). Huruf yang sama dibelakang angka pada satu kolom menunjukkan tidak berbeda nyata menurut uji Duncan pada $\alpha=0,05$.

pada tanaman kedelai. Meskipun isolat rizobakteri diintroduksi pada benih dan perakaran kedelai, tetapi mampu menghambat perkembangan Xag yang menginfeksi daun dan polong (filoplan). Mekanisme penghambatan patogen filoplan oleh bakteri antagonis diduga melalui induksi ketahanan secara sistemis (Induce Systemic Resistance, ISR). Plant Growth Promoting Rhizobacteri (PGPR) yang mengelisit ISR dan mampu meningkatkan ketahanan tanaman terhadap patogen filoplan, antara lain: pada mentimun terhadap Colletotrichum orizobakteria indigenusculare (Wei et al. 1991). Perlakuan benih dengan Pseudomonas fluorescens galur 97 dapat melindungi kacang buncis terhadap penyakit hawar kalang (halo blight) disebabkan oleh Pseudomonas syringae pv. phaseolicola (Alstrom, 1991). Perlakuan benih dengan P. putida galur 89B-27, Flavomonas oryzihabitans galur INR-5, S. marcescens galur 90-166 dan Bacillus pumilus galur INR-7 dapat melindungi tanaman mentimun secara sistemis terhadap penyakit daun bersusdut disebabkan oleh Pseudomonas syringae pv. lachrymans (Liu et al., 1995; Wei et al., 1996).

Grafik perkembangan insidensi dan severitas Xag pada tanaman kedelai yang diintroduksi dengan isolat rizobakteria indigenus dapat dilihat pada Gambar 2. Hampir semua isolat bakteri rizobakteri indigenus menunjukkan kecenderungan perkembangan insidensi penyakit pustul bakteri yang lebih rendah dibandingkan kontrol. Peningkatan perkembangan insidensi dan severitas penyakit pustul bakteri terjadi 12-27 hsi.

Hampir semua isolat rizobakteri indigenus yang diintroduksi pada kedelai mampu menurunkan intensitas dan severitas polong. Introduksi tanaman kedelai dengan 2 isolat rizobakteria indigenus (St2Rz2.1 dan St4Rz5.1) adalah yang terbaik dalam menurunkan insidensi dan severitas penyakit pustul bakteri pada polong (Tabel 3).

Pertumbuhan dan Hasil Tanaman Kedelai. Beberapa isolat rizobakteri indigenus mampu meningkatkan daya muncul lapang benih kedelai menjadi $100 \%$ dibanding dengan daya kecambah benih (92\%), sedangkan pada kontrol menurun $(88,33 \%)$ (Tabel 4). Tinggi tanaman kedelai setelah diintroduksi dengan isolat rizobakteri indigenus menunjukkan bahwa 2 isolat mampu meningkatkan tinggi tanaman, yaitu Pl4Rz1.1 (108,83 cm dan efektivitas 22,60 \%) dan Pl2Rz2.1 $(106,67 \mathrm{~cm}$ dan efektivitas $20,16 \%)$ dibanding kontrol $(88,76 \mathrm{~cm})$. Jumlah daun kedelai meningkat pada tanaman yang diintroduksi dengan semua isolat rizobakteri, 2 isolat yang terbaik adalah P14Rz1.1 (40,67 helai dan efektivitas $25,79 \%)$ dan Pl3Rz2.1 (39,33 helai dan efektivitas $21,66 \%)$. Jumlah cabang kedelai meningkat pada tanaman yang diintroduksi dengan isolat rizobakteri 

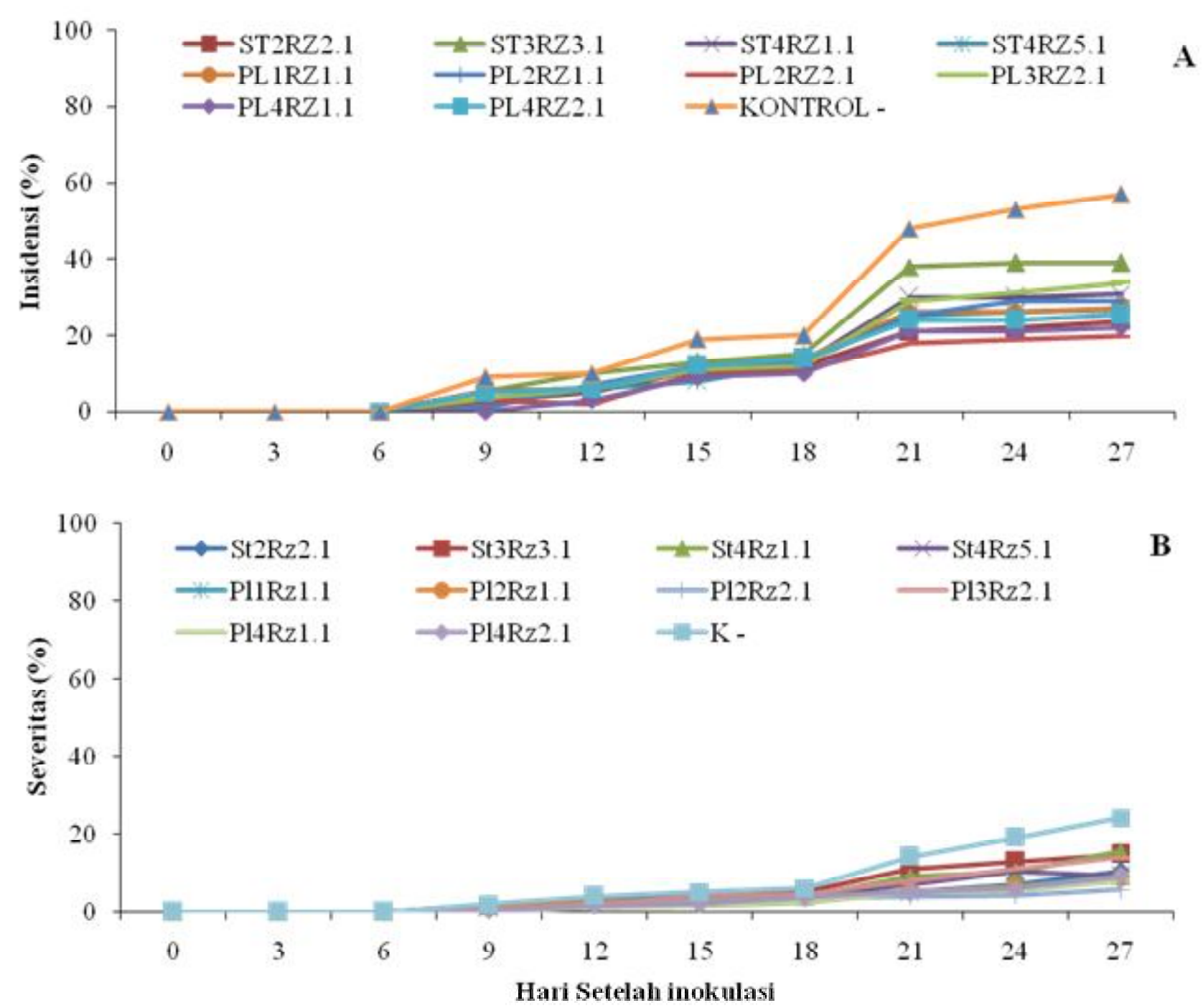

Gambar 3. Perkembangan penyakit pustul bakteri pada daun kedelai yang diinokulasi dengan Xag. (A) Insidensi dan (B) severitas.

indigenus, 1 isolat yang terbaik adalah Pl4Rz1.1 (7,67 tangkai dengan efektivitas 35,29\%).

Hampir semua isolat rizobakteri yang diintroduksi pada benih dan tanaman kedelai mampu meningkatkan pertumbuhan dan hasil tanaman. Isolat yang terbaik dalam meningkatkan pertumbuhan tanaman adalah P14Rz1.1 dan P13Rz2.1, sedangkan isolat yang terbaik dalam meningkatkan hasil kedelai adalah St3RZ3.1 dan Pl1Rz1.1. Dalam hal ini terlihat bahwa isolat rizobakteri yang mampu meningkatkan pertumbuhan tanaman tidak sekaligus mampu meningkatkan hasil tanaman. Kemampuan isolat rizobakteri dalam meningkatkan pertumbuhan tanaman telah banyak dilaporkan, antara lain aplikasi PGPR secara nyata dapat meningkatkan pertumbuhan tanaman cabai yang terinfeksi oleh CMV (Taufik et al., 2010).
Introduksi galur rizobacteri Pseudomonas fluorescens WCS417 pada tanah steril mampu memacu pertumbuhan Arabidopsis asesi Col-0 $33 \%$ (Pieterse \& Van Loon, 1999).

Saat muncul bunga dan polong pada tanaman kedelai setelah diintroduksi dengan isolat rizobakteri indigenus tidak berbeda dengan kontrol (Tabel 5). Berat basah dan berat kering biji kedelai meningkat pada tanaman yang diintroduksi dengan hampir semua isolat $\mathrm{RB}, 2$ isolat yang terbaik adalah St3Rz3.1 (berat basah 49,05 dan efektivitas $35,19 \%$; berat kering $33,31 \mathrm{~g}$ dan efektivitas 62,29\%) dan Pl1Rz1.1 (berat basah 48,56 dan efektivitas $33,84 \%$; berat kering $33,08 \mathrm{~g}$ dan efektivitas 60,97\%).

Hasil penelitian ini menunjukkan bahwa 1 isolat rizobakteria (P14Rz1.1) mampu mengendalikan penyakit 
Tabel 3. Insidensi dan severitas penyakit pustul bakteri pada polong setelah tanaman kedelai diintroduksi dengan isolat rizobakteria indigenus

\begin{tabular}{ccccc}
\hline \multirow{2}{*}{$\begin{array}{c}\text { Nama } \\
\text { isolat }\end{array}$} & \multicolumn{2}{c}{ Insidensi polong terserang } & \multicolumn{2}{c}{ Severitas polong terserang } \\
\cline { 2 - 5 } & $\%$ & Efektivitas $(\%)$ & $\%$ & Efektivitas (\%) \\
\hline P14Rz1.1 & 75,05 & 11,25 & $22,00 \mathrm{bc}$ & 41,20 \\
St2Rz2.1 & 58,06 & 32,45 & $16,33 \mathrm{c}$ & 55,21 \\
P12Rz1.1 & 78,92 & 7,92 & $23,66 \mathrm{bc}$ & 33,34 \\
P11Rz1.1 & 71,88 & 16,25 & $18,66 \mathrm{c}$ & 49,77 \\
P12Rz2.1 & 69,53 & 18,80 & $22,00 \mathrm{bc}$ & 40,96 \\
P14Rz2.1 & 79,62 & 7,10 & $24,66 \mathrm{bc}$ & 33,99 \\
St3RZ3.1 & 91,75 & $-7,05$ & $31,00 \mathrm{ab}$ & 13,51 \\
St4Rz1.1 & 76,23 & 11,06 & $24,66 \mathrm{bc}$ & 33,86 \\
St4Rz5.1 & 58,68 & 31,53 & $17,33 \mathrm{c}$ & 53,85 \\
P13Rz2.1 & 92,93 & $-8,42$ & $36,66 \mathrm{a}$ & 2,25 \\
Kontrol & 85,71 & 0,00 & $37,66 \mathrm{a}$ & 0,00 \\
\hline
\end{tabular}

${ }^{a}$ Efektivitas $=(\mathrm{K}-\mathrm{P} / \mathrm{K}) \times 100 \%, \mathrm{~K}=$ Kontrol dan $\mathrm{P}=$ Perlakuan. Huruf yang sama di belakang angka menunjukkan tidak berbeda nyata menurut uji Duncan pada $\alpha=0,05$.

Tabel 4. Pertumbuhan kedelai yang diintroduksi dengan isolat rizobakteria indigenus

\begin{tabular}{ccccccccc}
\hline \multirow{2}{*}{$\begin{array}{c}\text { Nama } \\
\text { isolat }\end{array}$} & \multicolumn{2}{c}{$\begin{array}{c}\text { Daya muncul } \\
\text { lapangan }\end{array}$} & \multicolumn{2}{c}{ Tinggi tanaman } & \multicolumn{2}{c}{ Jumlah daun } & \multicolumn{2}{c}{ Jumlah cabang } \\
\cline { 2 - 9 } & $\%$ & $\begin{array}{c}\text { Efektivitas } \\
(\%)^{\text {a) }}\end{array}$ & Cm & $\begin{array}{c}\text { Efektivitas } \\
(\%)^{\mathrm{b})}\end{array}$ & Helai & $\begin{array}{c}\text { Efektivitas } \\
(\%)^{\mathrm{b})}\end{array}$ & Tangkai & $\begin{array}{c}\text { Efektivitas } \\
(\%)^{\mathrm{b})}\end{array}$ \\
\hline P14Rz1.1 & 100,00 & 8,69 & 108,83 & 22,60 & $40,67 \mathrm{a}$ & 25,79 & 7,67 & 35,29 \\
St2Rz2.1 & 83,33 & $-9,60$ & 98,40 & 10,85 & $35,33 \mathrm{bc}$ & 9,29 & 6,33 & 11,64 \\
P12Rz1.1 & 100,00 & 8,69 & 102,10 & 15,02 & $33,67 \mathrm{c}$ & 4,13 & 5,67 & 0,00 \\
P11Rz1.1 & 100,00 & 8,69 & 100,97 & 13,74 & $34,33 \mathrm{bc}$ & 6,19 & 6,00 & 5,88 \\
P12Rz2.1 & 100,00 & 8,69 & 106,67 & 20,16 & $37,33 \mathrm{abc}$ & 15,47 & 6,33 & 11,64 \\
P14Rz2.1 & 83,33 & $-9,60$ & 97,50 & 9,83 & $34,00 \mathrm{c}$ & 5,16 & 6,00 & 5,88 \\
St3RZ3.1 & 100,00 & 8,69 & 99,60 & 12,20 & $33,33 \mathrm{c}$ & 3,10 & 6,00 & 5,88 \\
St4Rz1.1 & 100,00 & 8,69 & 90,73 & 2,21 & $32,67 \mathrm{c}$ & 1,04 & 6,00 & 5,88 \\
St4Rz5.1 & 83,33 & $-9,60$ & 97,66 & 10,02 & $35,00 \mathrm{bc}$ & 8,26 & 5,67 & 0,00 \\
P13Rz2.1 & 100,00 & 8,69 & 92,43 & 4,13 & $39,33 \mathrm{ab}$ & 21,66 & 6,00 & 5,88 \\
Kontrol & 83,33 & $-9,60$ & 88,76 & 0,00 & $32,33 \mathrm{c}$ & 0,00 & 5,67 & 0.00 \\
\hline
\end{tabular}

KK $=9,75 \% \quad \mathrm{KK}=8,63 \% \quad \mathrm{KK}=13,93 \%$

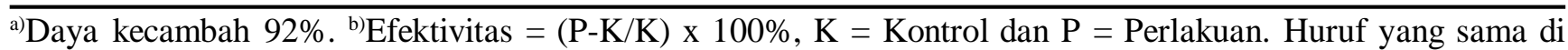
belakang angka menunjukkan tidak berbeda nyata menurut uji Duncan pada $\alpha=0,05$. 
Tabel 5. Perkembangan fase generatif dan hasil kedelai yang diintroduksi dengan rizobakteria

\begin{tabular}{cccccccccc}
\hline \multirow{2}{*}{ Isolat } & \multicolumn{3}{c}{$\begin{array}{c}\text { Saat muncul bunga } \\
\text { pertama }\end{array}$} & \multicolumn{3}{c}{$\begin{array}{c}\text { Saat muncul } \\
\text { polong petama }\end{array}$} & \multicolumn{2}{c}{ Berat basah biji } & \multicolumn{3}{c}{ Berat kering biji } \\
\cline { 2 - 10 } & Hst & $\begin{array}{c}\text { Efektivitas } \\
(\%)\end{array}$ & Hst & $\begin{array}{c}\text { Efektivitas } \\
(\%)^{\mathrm{a})}\end{array}$ & Hst & $\begin{array}{c}\text { Efektivitas } \\
(\%)\end{array}$ & Hst & $\begin{array}{c}\text { Efektivitas } \\
(\%)^{\mathrm{a})}\end{array}$ & Ton/ha \\
\hline P14Rz1.1 & 31,33 & 3,09 & 46,00 & 3,50 & $46,73 \mathrm{abc}$ & 28,80 & $26.19 \mathrm{abc}$ & 27,44 & 0,87 \\
St2Rz2.1 & 32,33 & 0,00 & 46,67 & 2,10 & $55.76 \mathrm{a}$ & 53,69 & $25.08 \mathrm{abc}$ & 26,90 & 0,84 \\
P12Rz1.1 & 31,67 & 2,04 & 46,67 & 2,10 & $43.17 \mathrm{bc}$ & 18,99 & $25.40 \mathrm{bc}$ & 23,60 & 0,85 \\
P11Rz1.1 & 32,00 & 1,02 & 47,33 & 0,71 & $48.56 \mathrm{ab}$ & 33,84 & $33.08 \mathrm{a}$ & 60,97 & 1,10 \\
P12Rz2.1 & 33,00 & $-2,07$ & 47,00 & 1,40 & $58.12 \mathrm{a}$ & 60,19 & $27.53 \mathrm{abc}$ & 33,96 & 0,92 \\
P14Rz2.1 & 32,00 & 1,02 & 47,33 & 0,71 & $37.32 \mathrm{bc}$ & 2,86 & $20.41 \mathrm{c}$ & $-0,68$ & 0,68 \\
St3RZ3.1 & 31,67 & 2,04 & 47,33 & 0,71 & $49.05 \mathrm{ab}$ & 35,19 & $33.31 \mathrm{a}$ & 62,09 & 1,11 \\
St4Rz1.1 & 32,00 & 1,02 & 47,67 & 0,00 & $43.48 \mathrm{bc}$ & $\mathbf{1 9}, 84$ & $29.17 \mathrm{ab}$ & 41,94 & 0,97 \\
St4Rz5.1 & 32,00 & 1,02 & 46,67 & 2,10 & $41.10 \mathrm{bc}$ & 13,28 & $24.58 \mathrm{bc}$ & 19,61 & 0,82 \\
P13Rz2.1 & 32,67 & $-1,05$ & 48,33 & $-1,39$ & $42.81 \mathrm{bc}$ & 17,90 & $30.38 \mathrm{ab}$ & 47,83 & 1.01 \\
Kontrol & 32,33 & 0,00 & 47,67 & 0,00 & 36,28 & 0.00 & $20,55 \mathrm{c}$ & 0,00 & 0,69 \\
\hline
\end{tabular}

$\mathrm{KK}=2,82 \% \quad \mathrm{KK}=3,78 \% \quad \mathrm{KK}=15,19 \% \quad \mathrm{KK}=16.57 \%$

${ }^{a}$ Efektivitas $=(\mathrm{P}-\mathrm{K} / \mathrm{K}) \times 100 \%, \mathrm{~K}=$ Kontrol dan $\mathrm{P}=$ Perlakuan. Huruf yang sama di belakang angka menunjukkan tidak berbeda nyata menurut uji Duncan pada $\alpha=0,05$.

pustul bakteri dan sekaligus meningkatkan pertumbuhan serta hasil tanaman kedelai. Isolat St3RZ3.1 memberikan hasil produksi polong yang tertinggi tetapi reaksi ketahanan tanaman kedelai terhadap Xag tergolong toleran.

\section{SIMPULAN}

Hampir semua isolat rizobakteri dari perakaran kedelai (indigenus) mampu mengendalikan penyakit pustul bakteri dan meningkatkan pertumbuhan dan hasil kedelai. Dua isolat rizobakteri (P12Rz2.1 dan P14Rz1) mampu mengendalikan penyakit pustul bakteri dan dua isolat P11Rz1.1 dan P14Rz1.1 mampu meningkatkan pertumbuhan dan hasil kedelai.. Dengan demikian, hasil penelitian ini diperoleh satu isolat terbaik yang mampu mengendalikan penyakit pustul bakteri dan meningkatkan pertumbuhan dan hasil kedelai yaitu P14Rz1.1.

\section{UCAPAN TERIMAKASIH}

Penelitian ini dibiayai oleh DP2M DIKTI DEPDIKNAS melalui Hibah Kompetisi Tahun 2010 dengan Kontrak NO. 429/SP2H/PP/DP2M/VI/2010 tgl. 11 Juni 2010. Untuk itu kami mengucapkan banyak terimakasih kepada Direktur DP2M DIKTI, DEPDIKNAS.

\section{DAFTAR PUSTAKA}

Adisarwanto T. 2009. Kedelai. Penebar Swadaya. Jakarta.

Badan Pusat Statistik (BPS). 2009. Statistik Indonesia.

Alstrom S. 1991. Induction of disease resistance in common bean susceptible to halo blight bacterial pathogen after seed bacterization with rhizosphere pseudomonads. J. Gen. Appl. Microbiol. 37:495501.

Chandrashekhara. 2007. Endophytic Bacteria from Different Plant Origin Enhance Growth and Induce Downy Mildew Resistance in Pearl Millet. J. Plant Pathology. 1(1): 1-11

Diniyah S. 2010. Potensi Isolat Bakteri Endofit sebagai Penghambat pertumbuhan Bakteri (Ralstonia solanacearum) dan Jamur (Fusarium sp. dan Phytopthora infestans) penyebab penyakit layu pada tanaman. Skripsi Fak. Sains dan Teknologi UIN Maulana Malik Ibrahim Malang.

Dirmawati S R. 2005. Penurunan Intensitas Penyakit Pustul Bakteri Kedelai melalui Strategi Cara Tanam Tumpangsari dan Penggunaan Agensia Hayati. Jurnal Agrijati 1 (1) 
Garrity GM. 2005. Bergey's Manual of Sistematic Bacteriology. Second Edition. Volume Two The Proteobacteria. Part B Gammaproteobacteria. Department of Microbiology and Molecular Genetics. Michigan State University.

Goradia L, Hartman GL \&Daniel S. 2004. Pathogenicity of Xanthomonas axonopodis pv. glycines, the Causative Agent of Bacterial Pustule in Soybeans. J. Biological Sciences 1(2) : 115-123

Habazar T. 1989. Inventarisasi Penyakit-Penyakit Bakteri Pada Tanaman Kedelai (Glycine max). Laporan Penelitian Pusat Penelitian Universitas Andalas Padang.

Habazar T, Nasrun, Jamsari \& Rusli I. 2007. Pola Penyebaran Penyakit Hawar Daun Bakteri (Xanthomonas axonopodis pv. allii) pada Bawang Merah dan Upaya Pengendaliannya melalui Imunisasi Menggunakan Rizobakteria. Laporan Hasil penelitian Universitas Andalas Padang dengan Litbang Pertanian Proyek KKP3T.

Habazar T, Yusniwati, Yanti Y, \& Resti Z. 2010. Pengembangan Teknologi Penapisan Rhizobacteria Indigenus Secara in Planta Untuk Mengendalikan Bakteri Patogen Tanaman. Laporan Penelitian th. I, Penelitian Hibah Kompetensi, DITLITABMAS, DIKTI. 53 hal

Hasanuddin A, Hidayat JR, \& Patohardjono. 2005. Kebijakan program penelitian kacang-kacangan potensial. Dalam Patohardjono, et al. (penyunting). Analisis dan Opsi Kebijakan Penelitian dan Pengembangan Tanaman Pangan. Monograf No.2, 2005. Puslitbangtan Bogor.

Joseph B ,Ranjan PR \&Lawrence, R. 2007. Charecterization of plant growth promoting rhizobacteria associated with chickpea (Cicer arietinum L.). J. Plant Production 1(2):141-151.

Khaeruni A, Suwanto A, Tjahjono B \& Sinaga SM. 2007. Deteksi Cepat Penyakit Pustul Bakteri pada Kedelai menggunakan Teknik PCR dengan Primer Spesifik. HAYATI J Biosciences 14(2):7680

Khamariah. 2010. Efektivitas Beberapa Isolat Bacillus subtilis Endofit indigenus dalam menekan serangan dan perkembangbiakan Nematoda Bengkak akar (Melodogyne spp.) Pada tanaman Tomat (Lycopersicum esculentum Mill). Skripsi. Fakultas Pertanian Universitas Andalas Padang.
Klement Z, Rudolph K, \& Sand DC. 1990. Methods in Phytobacteriology. Akademiai Kiado, Budapest.

Liu L, Kloepper JW, \& Tuzun S. 1995. Induction of systemic resistance in cucumber against bacterial leaf spot by plant growth promoting rhizhobacteria. Phytopathology 85:843-847.

Machmud M. 1987. Pengamatan Penyakit Pustul Bakteri dan Hawar Bakteri Kedelai. Dalam Gatra Penelitian Penyakit Tumbuhan dalam Pengendalian Secara Terpadu. Perhimpunan Fitopatologi Indonesia

Manuella M, Suwanto A \& Tjahyono B. 1997. Keefektifan Biokontrol Pseudomonas fluorescens B29 terhadap Xanthomonas campestris pv glycines in planta. Hayati, April:12-16.

Pieterse CMJ \& Van Loon LC. 1999. Salicylic acid independent plant defence pathways. Trends in Plant Science 4:52-58.

Rahayu M. 2007. Tanggapan Varietas Kedelai terhadap Penyakit Pustul Xanthomonas axonopodis pv. glycines dan Potensi Ekstrak Nabati untuk Pengendaliannya. Di dalam Inovasi teknologi kacang-kacangan dan umbi-umbian mendukung kemandirian pangan dan kecukupan energi. Prosiding Seminar Nasional Balai Penelitian Tanaman Kacang-kacangan dan Umbi-umbian Malang, 19 November 2007.

Rajendran L, Saravanakumar D, Ragunchander T \& Samiyappan R . 2006. Endophytic Bacterial Induction of Defence Enzymes Againts bacterial Blight of Cotton. Department of Plant Pathology, Centre for Plant Protection Studies, Tamil Nadu Agriculture University, Coimbatore-641003, Tamil Nadu, India.

Rukayadi Y, Suwanto A, Tjahjono B \& Harling R. 1999. Survival and Epiphytic Fitness of a Nonpathogenic Mutant of Xanthomonas campestris pv. glycines. App. Environ. Microbiol. 66 (3) : 11831189.

Semangun H. 1990. Pengantar Ilmu Penyakit Tumbuhan. Yogyakarta. Gadjah Mada. University Press.

Shiomi, Silva, Melo, Nunes \& Betiol. 2006. Bioprospecting Endophytic Bacteria for Bological control of Coffee Leaf Rust. Embrada Meio Ambiente-Lab de Microbiologia Ambiental, C.P.69-13820-000-Jaguariuna, SP-Brazil. 
Sinclair JB \&Backman PA. 1989. Compendium of Soybean Diseases. $3 \mathrm{rd} \mathrm{Ed}$. The American Phytopathological Society. United States of America.

Sivan A\& Chet I. 1986. Biological control of Fusarium spp. in cotton, wheat and muskmelon by Trichoderma harzianum. J. Phytopathology $116: 39-47$.

Supramana, Supriadi \& Harni R. 2007. Seleksi dan Karakterisasi Bakteri Endofit Untuk Mengendalikan Nematoda Peluka Akar (Prathylenchus brachyurus) Pada Tanaman Nilam. Laporan Hasil penelitian Institut Pertanian Bogor dengan Litbang Pertanian Proyek KKP3T.

Sweets L. 2010. Soybean Foliage Diseases may Begin to Show Up. J.Integrated Pest and Crop Management 20 (13): 102-105.

Taufik M, Rahman A, Wahab A, \& Hidayat SH. 2010. Mekanisme Ketahanan terinduksi oleh Plant Growth Promoting Rhizobacteria (PGPR) pada Tanaman Cabai Terinfeksi Cucumber Mosaik Virus (CMV). J. Hortikultura 20(3):274-283
Wei L, Kloepper JW \& Tuzun S. 1991. Induction of systemic resistance of cucumber to Colletotrichum orizobakteria indigenusculare by select strains of plant growth-promoting rhizobacteria. J. Phytopathology 81:1508-1512.

Wei L, Kloepper JW, \& Tuzun S. 1996. Induced systemic resistance to cucumber diseases and increased plant growth by plant growth promoting rhizobacteria under "eld conditions. $J$. Phytopathology 86 : 221-224.

Yanti Y \& Resti Z. 2010. Induksi ketahanan tanaman bawang merah dengan bakteri rhizoplan indigenus terhadap penyakit hawar daun bakteri (xanthomonas axonopodis pv allii). Dalam Loekas Soesanto, Endang Mugiastuti, Ruth Feti Rahayuniati dan Abdul Manan (Ed).Prosiding seminar nasional pengelolaan opt ramah lingkungan Purwokerto,10-11 November 2010. 